Social Museology and the Iny Karajá Health Campaign in Brazil

Muséologie sociale et l'action de santé Iny Karajá

Manuelina Maria Duarte Cândido, Andréa Dias Vial, Henrique Gonçalves Entratice, Rafael Santana Gonçalves de Andrade and Nei Clara de Lima

\title{
OpenEdition
}

12 Journals

Electronic version

URL: https://journals.openedition.org/iss/3177

DOI: 10.4000/iss.3177

ISSN: 2306-4161

Publisher

ICOM - International Council of Museums

Printed version

Date of publication: 18 December 2021

Number of pages: $77-90$

ISBN: 978-92-9012-446-7

ISSN: 2309-1290

Electronic reference

Manuelina Maria Duarte Cândido, Andréa Dias Vial, Henrique Gonçalves Entratice, Rafael Santana Gonçalves de Andrade and Nei Clara de Lima, "Social Museology and the Iny Karajá Health Campaign in Brazil", ICOFOM Study Series [Online], 49-1 | 2021, Online since 18 December 2021, connection on 08 January 2022. URL: http://journals.openedition.org/iss/3177 ; DOI: https://doi.org/ 10.4000/iss.3177 


\section{Social Museology and the Iny Karajá Health Campaign in Brazil}

Manuelina Maria Duarte Cândido

Prof. of Museology at University of Liège, Belgium and Prof. at PPGAS-UFG, Brazil

\section{Andréa Dias Vial}

Independent Researcher, PhD in History from FFLCH-USP - São Paulo, Brazil

\section{Henrique Gonçalves Entratice}

PhD student in Anthropology at NOVA University of Lisbon - School of Social Sciences and Humanities (NOVA FCSH) and Integrated Member at Institute of Contemporary History (IHC)

Rafael Santana Gonçalves de Andrade PhD student at the National Museum - UFRJ Rio de Janeiro, Brazil 


\section{Nei Clara de Lima \\ Retired Professor at FCS-UFG - Brasília, Brazil}

\section{A B STRACT}

Drawing on Social Museology principles, this document presents and analyses the activities carried out in 2020 as part of the Karajá Presence Research Project, launched in 2017, into material culture, fabric, and colonial transits. We show how the mapping and study of collections of indigenous artifacts led to a health campaign in support of the Iny Karajá people. This group holds the knowledge related to the production of ritxoko, clay dolls which are the subject of our investigation. Furthermore, we share our understanding that life is the most significant heritage. Working for the survival of biological and cultural diversity must be a non-negotiable commitment of Museology since it is a domain that looks at the fate of things and their continuity.

Keywords: Social Museology, musealisation, intangible heritage, Iny Karajá, Brazil, Covid-19, indigenous health

\section{RESUMÉE}

\section{Muséologie sociale et l'action de santé Iny Karajá}

Ce document présente et analyse, à la lumière des fondements de la Muséologie sociale, des actions menées en 2020 dans le cadre du projet de recherche Présence Karajá: culture matérielle, trames et transits coloniaux, lancé en 2017. Nous réfléchissons ici au processus qui a conduit à une étude de cartographie et d'étude des collections d'artefacts indigènes à mener une campagne de soutien sanitaire du peuple Iny Karajá, groupe détenteur des savoirs liés à la production des ritxoko, des poupées sur lesquelles on enquêtait. Et nous partageons avec le public lecteur la compréhension que la vie est le plus grand patrimoine, et que travailler pour la survie de la diversité biologique et culturelle doit être un engagement non négociable de la Muséologie, en tant que domaine qui se penche sur le destin des choses et sur les pérennités.

Mots-clés : Muséologie sociale, muséalisation, patrimoine immatériel, Iny Karajá, Covid-19, santé indigène.

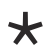


Drawing on Social Museology, in this paper we present and discuss a health campaign developed in 2020 within the Karajá Presence Research Project into material culture, patterns and colonial influences, started in 2017 and coordinated by Prof. Dr Manuelina Duarte and Prof. Dr Nei Clara de Lima. The project relies on students, professionals, researchers, and professors from institutions in Brazil and abroad, ${ }^{1}$ and is run by the Faculty of Social Sciences (FCS) and the Anthropological Museum of the Federal University of Goiás (UFG).

The Karajá Presence Project (PPK) aims to research ritxoko collections in institutions, tracing their origins and distribution, the contacts among researchers, institutions and Iny Karajá indigenous groups, and studying the ritxoko body adornments and costumes. Additionally, we explore the dialogue between Anthropology and Social Museology, to contribute to the studies of heritage, museums, collections, and material culture. To date, the research has identified ritxoko collections in 75 museums in 16 countries.

The Iny Karajá women have been producing ritxoko since time immemorial. Ritxoko are figures made from raw or baked clay and wax; they are produced in Iny Karajá villages located in the Araguaia river valley region, which covers the states of Goiás, Mato Grosso, Tocantins and Pará (Lima, 2011; Lima, Filho \& Silva, 2012; Lima \& Leitão, 2016; Silva, 2015).

\section{The COVID-19 Pandemic and the New Challenges Faced by the Karajá Presence Project}

With a team spread out geographically, remote working, especially for meetings, was already part of our project's methodology, but the advent of the coronavirus pandemic reinforced this aspect. The pandemic would have other significant impacts on the progress of the project: after May 2020, the possible collapse of the health system in the region of the Karajá villages at the Araguaia River Valley became a cause for concern for the group. At that time, we had no news of sick people in the region, but we knew from other sources that the indigenous communities across Brazil were at risk from the spread of Covid-19. In April 2020, a team of researchers and professionals from the Brazilian Institute

\footnotetext{
I. The team in 2020: Labé Iny (Graduated from the UFG Indigenous Intercultural Degree Course); Dibexia Karajá (Student of the UFG Indigenous Intercultural Degree); Sawakaru Kawinan (young indigenous leadership in the Buridina village); Prof. Dr. Manuelina Maria Duarte Cândido (FCSUFG and Université de Liège, Belgium) - Coordinator; Prof. Dr. Nei Clara de Lima (Retired Professor at FCS-UFG) - Vice-coordinator; Prof. Dr. Ema Cláudia Ribeiro Pires (University of Évora, Portugal); Prof. Dr. Rita Morais de Andrade (FAV-UFG); Dr. Andréa Dias Vial (PhD in History from FFLCH, USP); Dr. Luciana Conrado Martins (PhD in Education from FE, USP); Indyanelle Marçal Garcia Di Calaça (PhD student FAV-UFG); Rafael Santana Gonçalves de Andrade (PhD student at the National Museum - UFRJ); Bárbara Freire Ribeiro Rocha (Master in Arts, Heritage and Museology at UFPI); Henrique Gonçalves Entratice (PhD student in Anthropology at Universidade Nova de Lisboa); Thaís Maia de Souza (Bachelor in Museology, FCS-UFG); Markus Garscha (Photographer); Amanda Carlotti dos Santos (Student of Museology, FCS-UFG).
} 
of Geography and Statistics (IBGE) published a report on demographic and infrastructural vulnerability in indigenous protected territories to Covid-19 (Azevedo et al., 2020). They created an index (IVDIC) classifying the degree of vulnerability of indigenous territories between 0 and 1 : the closer to 0 , the more moderate the degree of vulnerability, and the closer to 1 , the more critical. In the indigenous territory Parque do Araguaia, along the borders between the states of Tocantins (TO), Goiás (GO), Mato Grosso (MT), and Pará (PA), most of the Iny Karajá villages display a degree of vulnerability between 0.30 and 0.39, which is considered high in the IBGE's report (Azevedo et al., 2020, p. 11).

In 2020, the IBGE commissioned the same team of researchers to develop a new index using the same methodology of the IVDIC with a different set of data gathered by Special Indigenous Health Districts (DSEIs). In the study presented in April 2020, the DSEI Araguaia, located at São Félix do Araguaia (MT) and responsible for most Iny Karajá villages, rated them with a high vulnerability level of 0.426 (Azevedo et al.,2020, p. 18). This was due to the lack of adequate healthcare equipment, the lack of staff, and other reasons related to the fact that the DSEI Araguaia is responsible for overseeing, in addition to the Iny Karajá, six other different ethnic groups in eight indigenous lands, covering a total of 40 villages.

Karajá villages in the Araguaia Valley region comprise a broad strip of territory along the Araguaia River, encompassing at its extreme southern limit villages in the municipality of Aruana (GO), to villages in the city of Santa Maria das Barreiras (PA), at its northern limit. However, most villages are on "Bananal Island," with a total estimated population of 4,326, according to the last IBGE census (IBGE, 2010). Thus, it is a large population, spread over a significant territory, making it more difficult to deliver emergency and complex medical care requiring intensive care units and ventilators, necessary for the treatment of the most severe Covid-19 cases.

That information, added to the daily news about the increasing numbers of cases in Brazil and the collapse of the public health system in various regions of the country, brought a new urgency to the Karajá Presence team's discussions on how to act. We decided to start the Iny Karajá indigenous health campaign to raise money for the production and delivery of reusable masks to protect the Iny Karajá people during the Covid-19 pandemic.

\section{Preserving the Lives of Holders of Cultural Heritage as Both a Fundamental Right and a Cultural Right}

Although the PPK aims to investigate Karajá dolls as cultural heritage and "musealised" (Desvallées \& Mairesse, 2013/2010) cultural assets, we believe that mounting a health campaign to protect the Iny Karajá people was within the project's general scope because life is the most significant heritage. The research 
into and "heritagisation"2 (Harrison, 2013) of indigenous peoples' cultural assets should, first and foremost, contribute to ensuring that these peoples, holders of unique cultural repositories, have access to the Fundamental Rights to live in society. As Dr Luiz Eloy Terena, a native lawyer and activist and the Head of the Legal Department of the Articulation of Indigenous Peoples of Brazil (APIB), has argued during a legal process, the richness of native ancestral culture is guarded and preserved by the natives' lives. ${ }^{3}$

In addition to the ethical commitment, actions based on Social Museology seek to engage local social groups in transforming heritage into an instrument of local development, including improving quality of life and acting on issues that are fundamental to these groups, even though, at first, they might seem outside the primary objectives. As a result, even if not planned a priori, the health campaign paved the way for the project to contact and be contacted by many indigenous people from different villages, creating new partnerships. Finally, it allowed project members to experience some of the infrastructure difficulties faced by the indigenous population regarding access to villages, the logistics of distributing goods, as well as issues of prejudice and neglect in social and health care.

Over the past four years, public policies to protect traditional communities in Brazil have been less effective in providing these communities with their fundamental rights, and different fronts of resistance have emerged. Among them, the Articulation of Indigenous Peoples of Brazil (APIB), together with six political parties, joined the Clinic for Fundamental Rights of the University of the State of Rio de Janeiro (UERJ) to use constitutional measures seeking to contain the spread of the Covid-19 virus in these territories. They proposed a legal action demanding the federal government install sanitation barriers around indigenous territories, among other specific demands. At the time of writing, this legal action, $A D P F 709,{ }^{4}$ is awaiting judgment by the Supreme Court.

Article 215 of the Federal Constitution of 1988 says that the State is responsible for protecting the manifestations of popular, indigenous, and Afro-Brazilian cultures. It is one of the main instruments within the Brazilian legal system concerning the State's Cultural Rights protection. In 1993, UNESCO created the Living Human Treasures program, which encouraged the Member States to grant official recognition to people with the knowledge of traditional cultural practices, thus acknowledging their importance and the need to trans-

\footnotetext{
2. We use the word heritagisation to describe the process by which objects, places and practices are turned into cultural heritage.

3. "Lives that guard our most valuable wealth, which is the ancestral culture of our peoples," ADPF 709/2020 (Statement of Non-Compliance with Fundamental Precept, 2020, p. 82). The ADPF are actions of full control of constitutionality whose objective is to prevent any act of the Public Power that corrupts the fundamental precepts proposed by the 1988 Federal Constitution.

4. ADPF number 709/2020 - Statement of Non-Compliance with Fundamental Precept.
} 
mit knowledge to new generations. The program personalised the protection of cultural goods through the holders of knowledge, especially the elders. It was discontinued in 2003, after the introduction of the Convention for the Safeguarding of the Intangible Cultural Heritage, given the anthropological character of the concept of cultural heritage in the international legal system. The protection of people, their knowledge, and their right to pass on that knowledge to the next generation has been on the agenda for almost 30 years within UNESCO. Safeguarding Brazilian cultural heritage also guarantees the constitutional order of access to healthcare for native peoples so that their societies might not be so severely affected by pandemics, as has happened in the past. Furthermore, it is essential to note that older people, among them many ceramists with the know-how of ritxoko, are the most at-risk group of the Covid-19 disease.

At the international level, museums and collections have their role recognized as human rights activists since the promulgation of the 1948 Universal Declaration of Human Rights, especially in article 27. UNESCO published, in 2015, "Recommendation on the Protection and Promotion of Museums and Collections, their Diversity and their Role in Society." For the first time in a UNESCO text, the document incorporates the social function of museums defended in the Declaration of Santiago de Chile, 1972.

Facing the fact that the Executive Branch of the Brazilian government did not fulfill its constitutional duty to guarantee access to healthcare and protection of first peoples prompted the PPK's team to step in to help protect Iny Karajá people's health and thus their cultural heritage.

\section{Expanding Concepts in the Field of Cultural Heritage and Museology to Include the Preservation of Life}

The concept of cultural heritage is continuously reframed (Choay, 2001). What thinkers of the field call "cultural heritage" or "cultural assets", traditional communities see as their lives and daily practices of building and transmitting knowledge.

An indigenous way of thinking asks, in a perceptive way, why so-called Western epistemologies and institutions are satisfied with preserving examples or fragments of cultural and natural heritage:

When we wanted to create a biosphere reserve in a region of Brazil, it was necessary to justify to UNESCO why it was important that the planet was not devoured by mining. For this institution, it is as if it were enough to keep only a few places as a free sample of the Earth. (Krenak, 2019, p. 8) 
The statement exposes "the emperor's new clothes": i.e., piecemeal preservation, in self-contained and unconnected categories, seems to serve to legitimise the destruction of everything else, while native thought resists this compartmentalised and utilitarian view of things. To our team, it always seemed clear that so much dedication and appreciation for ritxoko out of context and preserved in museums did not make sense if the people who produce them were at risk of disappearing. For this reason, musealisation, more usually associated with the material heritage housed by these institutions, should, in our view, be connected to the process of "heritagisation" of intangible (i.e., living) heritage, which we have seen since 2012. We question and test the boundaries between these processes within our project, carried out in our country under the aegis of two different institutions. ${ }^{5}$ Quite often, the concern to define specificities and avoid shadowing between actions requires the construction of walls rather than interlocutions.

The Karajá Presence Project decided to carry out the Iny Karajá indigenous health campaign based on an understanding of the wider definition of cultural assets, which encompasses material and non-material production, as well as the assets' holders, and guided by an ethical commitment to the first nations, in this case the ceramists and their families, producers of ritxoko. We also align ourselves with the Córdoba Declaration, XVIII International Movement for a New Museology (MINOM) Conference, which states: "A Museology that is not life-oriented is not worthy."

\section{Rethinking Museology in Light of the Pandemic}

In this case, it is not a question of thinking about the museum's social function, since the project was not developed only in one institution, but of seeing Museology as an area of knowledge with a broader scope. Museology does not develop itself within the limits of the museal field (Desvallées \& Mairesse, 2013/2010). According to theoretical lines ${ }^{6}$ that understand it as a discipline or as an applied social science that studies the relationship between humans and objects in context, it can extend its interpretation and seek to transform research into actions that can positively impact the lives of those peoples who are bound up with their local heritage (Varine, 1994; Duarte Cândido, 2003).

So, we understand the PPK as a study of Museology not carried out in a specific museum, and which is interested in the musealisation process of the pieces made by Karajá ceramists who live along the Araguaia River. Furthermore, if there are doubts about whether or not it is Museology, we have rigorously tested the boundaries between the categories of musealisation and "heritagisation." The inclusion of Karajá dolls or ritxoko in museums in Brazil and abroad, since the end of the $19^{\text {th }}$ century, dramatically anticipates their later appreciation as

5. The Institute of National Historical and Artistic Heritage (IPHAN) and the Brazilian Institute of Museums (IBRAM) in Brazil.

6. The concept of "museal fact" advocated by Waldisa Rússio (I990). 
non-material or intangible heritage, a category only incorporated by UNESCO in 2003 and by Brazilian legislation in 2000.

Nevertheless, preserving cultural heritage, whether tangible or intangible, should not, in our opinion, take place separately from caring for and valuing people, especially the portion of the population that holds this cultural heritage. Regarding the preservation of cultural heritage, it is essential to point out that during presentations about this research, especially outside Brazil in countries where perhaps the notion of a museum object is more associated with criteria such as rarity and uniqueness, it is common to ask how old the dolls are or how rare they are. These questions do not apply to the ritxoko since the Iny Karajá women continue to produce them. Another aspect concerns the dissemination of photographs of the ritxoko dolls from the museums' collections that we have been studying. Throughout the negotiations to obtain rights to publish these images on a single digital platform, to enable wider access, some museums have been concerned that publicising the dolls might increase the risk of theft, especially from those museums that do not have a good security system. We have a different view. Although the ritxoko dolls are listed as cultural heritage, they do not constitute exceptional and valuable objects that might attract the antique market's attention, precisely because they are still being produced. They are living heritage. According to the perspective of Labé Iny, a member of the PPK team:

The ritxoko has a very important [place] in the social and cultural function in the Iny Karajá world. Therefore, it is imperative to have access to the pictures of the oldest ritxoko dolls spread around the world. If they put together all these pictures in a single digital platform, it would facilitate access and [allow] Iny Karajá people to remember, refresh memories and update. The digital platform will help regain knowledge about these dolls. It can show the pictures to elders and wise women in the village who make these dolls. It is worth mentioning that it is essential to compare the oldest photos with the new ones. This tool will provide a resumption of dolls no

longer made by Iny Karajá women and encourage the manufacture of new dolls.

(as cited in Duarte Cândido, Secches, Martins, \& Vial, 2020)

As we have seen, the Córdoba Declaration calls on MINOM to take another stance, committed first and foremost to preserving life. In the context of our society's illness, of which the COVID-19 pandemic seems to be a result, repositioning our thinking according to more integrative epistemologies is seen as fundamental: "The dialogue among the Biology of Knowledge, Living Well, and Ubuntu should provide a vision of Museology that is above all respectful 
and radically supportive of the communities in which we work" (Siqueira, 2019, p. 176).

The Iny Karajá health campaign ${ }^{7}$ was based on crowdfunding. The research to choose the platform that best suited the needs of the campaign looked for those that would charge a lower percentage for their use, those that would facilitate the registration of people and donations, and finally, those that made international donations possible. The presentation text was prepared in Portuguese and English to guarantee the accessibility of information beyond Lusophone countries.

The health campaign was initiated on June 19, 2020, with a global target of R\$ 35,000. At that time, the objective was to purchase and deliver 9,000 fabric masks. The health campaign's communication strategy was to send emails to contact networks of people involved with the Project and communicate via social networks (Facebook and Instagram). Through banners and informational videos shared on the networks, the PPK also sought partnerships with far-reaching media. Our communication partners were the "342amazônia" and "Mídia India" Instagram profiles, totalling 250,700 followers, and the Web portal "Jornal GGN," which published a note that was read 432 times. The health campaign attracted 218 supporters who donated a gross amount of R \$19,375.66 (approximately 3,150 euros), representing more than half of the global target reached. International donations made up $16.09 \%$ of the total amount, with the remainder coming from 17 different states in Brazil. The net amount raised was $\mathrm{R} \$ 18,177.76$, after deducting the fee charged by the platform, which was R $\$ 1,197.90$.

An important point is that during the health campaign, the PPK was sought out by different indigenous leaders (primarily young people). After hearing about the health campaign, they contacted the PPK with requests for additional supplies to deal with the spread of the virus among the Iny Karajá people. Thus, we reduced the deliveries of masks, which the villages began to receive from other donations. We decided to attend to their demands to include other items such as digital thermometers and oximeters, facial protectors, and waterproof boots for indigenous health workers. The Iny Mahadu Women's Collective organised most of the deliveries. We were also able to purchase some of the 2,700 cloth masks produced by the Sateré-Mawé Indigenous Women's Association of Manaus, using the same amount of the money to benefit another indigenous group.

\section{Final Considerations}

The emergency health campaign to support Iny Karajá people during the COVID-19 pandemic led to a re-evaluation of the scope of the project, which

7. Organised by the PPK researchers, it was also supported by the Faculty of Visual Arts at UFG through its Indumenta Research Group: dress and textiles studies in Brazil. 
reinforced some theoretical premises already assumed by the team, as well as opening up the possibility of new paths for the continuity of the work yet to be developed.

Since its beginning, the PPK has been attentive to the scope of its actions and the research results. The team's work has always been concerned with the dialogue between the project's partner institutions, museums, researchers, ceramicists, and indigenous leaders. The collections mapping, in this sense, has developed from a broad space for dialogue and debate that involves different actors and areas. In this process, it is essential to stress how the fundamental work of Iny Karajá professionals and students in the project team has resulted in.

Coevality as a way of sharing the past to be consciously in each other's present (Fabian, 2013) has been incorporated into how the Karajá Presence Project team has worked on mapping the ritxoko collections in museums around the world. Consciously sharing the reality of the present time among the project team, institutions, ceramicists, and others, Iny Karajá means being aware of the historical (Pacheco de Oliveira, 2016) and political situation connecting the project's researchers and its stakeholders. Moreover, it involves ethical and political commitments to vulnerable populations in light of the advancement of neo-colonialist forms of exploitation of capital made by Brazil's current government. We understand that research does not happen apart from the adversities of daily life or the critical events that occasionally affect us, such as a pandemic that has had many unexpected and tragic consequences worldwide.

At the same time, taking emergency action in favour of Iny Karajás health reinforced for the group the need to do "involved ethnology", understanding that the work done by the Karajá Presence Project also operates with the intention to transform certain realities, as proposed by Alban Bensa:

What good are the social sciences if they cannot put their tools and results at the service of necessary social transformations? To be involved in the political debate, far from becoming corrupted or trivialised, ethnology seemed, while we were responding to a moral requirement, to be able to be eventually enriched by a reflection on the transitory and circumstantial nature of its proposal. Expert arguments are difficult to dissociate from political views. Elucidating a situation is independent of the will to transform it, and any observation can provide the means of overcoming it. $(2006, \text { p. 276) })^{8}$

Thus, we try to converge objectives anchored in Anthropology and Social Museology theories, which are also committed to the transformation of reality

8. Translated from French by the author. 
and the valorisation of subjects, having the museum and heritage as instruments, and not as an end in themselves.

We also understand that the pandemic, affecting the most vulnerable in an even more overwhelming way, has been a wake-up call for the whole of humanity to the risk of discontinuity. Therefore, it should be a lesson to the so-called Western societies, blinded by their arrogance, who seem unable to read the signs from nature that are crystal-clear for indigenous peoples. According to Ailton Krenak ${ }^{9}$ :

What I have learned over the decades is that everyone needs to wake up. If for a time, we, the indigenous peoples, were those threatened with the disruption or extinction of our lives' senses, today we are all facing the imminent threat of the Earth no longer meeting our demand. (2019, p. 23)

Working for the survival of indigenous groups and biodiversity is a commitment, an opportunity to keep other world readings alive and, therefore, the only possible way to reverse the processes that ushered in the Anthropocene and that threaten us now. We understand Museology as an area that is interested in the fate of things ${ }^{10}$ (Bruno, 2009), so it is also necessary to be sensitive to the future of the populations and more vulnerable ecosystems whose potential losses represent the disappearance of repertoires, of ways of living and opportunities for "Living Well." "The International Movement for a New Museology has pointed to the potential of connecting reflection and museological practices with the search for a "Living Well" way of life. To this end, Luis Fernando Novoa Garzon (2016, as cited in Brayner Rangel, 2020) stated in his speech at the $17^{\text {th }}$ MINOM Conference, at Nazaré, Rondônia, Brazil:

9. Ailton Alves Lacerda Krenak is a Brazilian writer, journalist, philosopher, and indigenous movement leader of Krenak ethnicity.

Io. We take "things" here not only as material artifacts but as in Ingold's (20I2) perspective: The object stands before us as a fait accompli, presenting its congealed, outer surfaces to our inspection. It is defined by its very 'over-againstness' in relation to the setting in which it is placed (Heidegger [ [971]). The thing, by contrast, is a 'happening,' or rather, a place where several happenings become entwined. To observe a thing is not to be locked out but to be invited in to the gathering. (...) Thus conceived, the thing has the character not of an externally bounded entity, set over and against the world, but of a knot whose constituent threads, far from being contained within it, trail beyond, only to become caught with other threads in other knots. In a word, things leak, forever discharging through the surfaces that form temporarily around them. (p.I67)

II. Living Well is a concept based on indigenous thinking that problematises notions like development, even a sustainable one, considering it a fallacy. Vânia Brayner is one of the authors who evokes this concept as a relevant theme for our field (see, for example, Brayner Rangel, 2020, p. 405), and, to this end, she puts herself decisively in an anti-capitalist position. 
We should not forget that to think about the new museology is to think about perennity. To combat this official amnesia policy, this policy of forgetting aims to cleanse from our imaginations, from our practices, any criticism that can sustain any alternative practice. (p. 202)

This is the only way that Museology can position itself to preserve alternative ways of life and to meet the overwhelming challenges faced by historically subjugated peoples, such as the indigenous people. Only then will Museology be close to the populations deliberately targeted by the "official policy of amnesia" and even "ethnic cleansing," for which even the pandemic seemed to be particularly useful. Only then will Museology be with them (in this case, the indigenous people), "na hora do tombo do pau," 12 which means to say, "when the confrontation breaks out, and the repression grows."

This text is dedicated to the memory of the indigenous people who died among the Iny Karajá people before the date of the project's completion, 30/08/2020: Wereni Tapirapé - Village Itxalá, MT (20/07); Komytira Karajá - ceramicist - Village Santa Isabel do Morro, TO (26/07); Koaxiru Karajá - ceramicist - Village Santa Isabel do Morro, TO (14/08); Isarire Lukukui Karajá - Village Santa Isabel do Morro, TO (15/08); Kualaru Karajá - Professor Leandro Lariwana's mother (15/08); Lorinaru Karajá - Djuassa Karajá's mother (14/08); Hatiure Karajá - Village Fontoura, TO (16/08); Hawakate Karajá, Village Santa Isabel do Morro, TO (28/08).

\section{References}

Azevedo, M., Damasco, F., Antunes, M., Martins, M. H., \& Rebouças, M. P. (2020). Análise de vulnerabilidade demográfica e infraestrutural das terras Indígenas à Covid-19: Cadernos de insumos. Associação Brasileira de Estudos Psicanalíticos do Estado de Pernambuco.

Bensa, A. (2006). La fin de l'exotisme: Essais d'anthropologie critique. Anacharsis. Brayner Rangel, V. M. A. (2020). Memórias rebeldes: A invenção clássica e sua transfiguração em processos sociomuseais decoloniais e ecossistêmicos [Unpu-

\footnotetext{
I2. The expression refers to one of the epigraphs used by Brayner (2020) in her thesis. It takes up the speech of a peasant in the book Pedagogia da esperança [Pedagogy of hope], written by the Brazilian educator Paulo Freire, a great inspiration for social museology (1974, as cited in Brayner Rangel, 2020): "If you came here thinking about teaching us that we are exploited, you don't need to do so because we already know it very well. Now what we want to know from you is whether you will be with us 'na hora do tombo do pau' [which means 'when confrontation breaks out, and the repression grows']" (p. 403).
} 
blished doctoral dissertation]. Universidade Lusófona de Humanidades e Tecnologias.

Bruno, C. (2009). Estudos de cultura material e coleções museológicas: Avanços, retrocessos e desafios. In M. Granato \& M. F. Rangel (Eds.), Cultura material e patrimônio da ciência e tecnologia, (pp. 14-25). Museu de Astronomia e Ciências Afins.

Choay, F. (2001). A alegoria do patrimônio. São Paulo State University.

Declaración de Córdoba (2017). XVIII Conferência Internacional de MINOM: La museología que no sirve para la vida, no sirve para nada. MINOM-ICOM. http://www.minom-icom.net/noticias/minom-cordoba-declaration2017-es-pt-fr-en

Desvallées, A., \& Mairesse, F. (2013). Conceitos-chave de museologia. (B. Brulon Soares \& M. X. Cury, Trans.). ICOM Brasil, Comitê Brasileiro do Conselho Internacional de Museus. (Original work published 2010)

Duarte Cândido, M. M. (2003). Ondas do pensamento museológico brasileiro. Cadernos de Sociomuseologia, 20(20). Universidade Lusófona de Humanidades e Tecnologias.

Duarte Cândido, M. M., Secches, I.L., Martins, L.C., Vial, A.D., \& Fabian, J. (2020). Material for dissemination of 'Presença Karajá' project + Tainacan platform [Unpublished PowerPoint Slides]. (G. Costa de Figueiredo, Trans.). Université de Liège. http://hdl.handle.net/2268/256016

Harrison, R. (2013). Heritage: Critical approaches. Routledge.

Ingold, T. (2012). Trazendo as coisas de volta à vida: emaranhados criativos num mundo de materiais. Horizontes Antropológicos, 18(37), 25-44. https:// dx.doi.org/10.1590/S0104-71832012000100002

Instituto Brasileiro de Geografia e Estatística. (2010). Censo demográfico: Características gerais dos indígenas. Resultados do universo. Ministério do Planejamento, Orçamento e Gestão.

Krenak, A. (2019). Ideias para adiar o fim do mundo. Companhia das Letras.

Lima, N. C. de, Silva, T. C. da, Corrêa, M. T., Lima Filho, M. F. \& Leitão, R. M. (2011). Bonecas Karajá: arte, memória e identidade indígena no Araguaia: Dossiê descritivo do modo de fazer ritxoko. Museu Antropológico, Universidade Federal de Goiás.

Lima, N. C. de, \& Leitão, R.M. (2016). Bonecas Karajá como Patrimônio Cultural do Brasil: da pesquisa à salvaguarda [Unpublished manuscript]. Universidade Federal de Goiás. https://files.cercomp.ufg.br/weby/up/322/o/ Artigo5.pdf?1453825313 
Lima Filho, M.F., \& Silva, T. C. (2012). A Arte de saber fazer grafismos nas bonecas Karajá. Horizontes Antropológicos, 18, 45-74. https://dx.doi.org/10.1590/ S0104-71832012000200003

Pacheco de Oliveira, J. (2016). O nascimento do Brasil e outros ensaios: Pacificação, regime tutelar e formação de alteridades. Contra Capa.

Russio Guarnieri, W. (1990). Conceito de cultura e sua inter-relação com o patrimônio cultural e a preservação. Cadernos Museológicos, 3, 7-12.

Siqueira, J.M. de (2019). A educação museal na perspectiva da sociomuseologia: Proposta para uma cartografia de um campo em formação (Vol. 1) [Unpublished doctoral dissertation]. Universidade Lusófona de Humanidades e Tecnologias.

Silva, T. C. da (Ed.). (2015). Ritxoko. Cânone Editorial.

Statement of Non-Compliance with Fundamental Precept [ADPF case number 709]. (2020). Supremo Tribuno Federal.

Varine-Bohan, H. (1994). Le musée peut tuer... ou faire vivre. In A. Desvallées (Ed.), Vagues: Une anthologie de la nouvelle muséologie (Vol. 2), (pp. 65-73). Edition W, MNES. 